\title{
Trace Mineral Status in Goats in Different Zones of Punjab State, India
}

\author{
Gurwinder Singh*, Sushma Chhabra and S.K. Uppal \\ Department of Veterinary Medicine, Guru Angad Dev Veterinary and Animal Sciences \\ University, Ludhiana- 141004, Punjab, India \\ *Corresponding author
}

\section{A B S T R A C T}

\begin{tabular}{|l|}
\hline Ke y w or d s \\
Zones, Goats, \\
Plasma, Hair, \\
Copper, Zinc, Iron, \\
Manganese \\
\hline Article Info \\
\hline $\begin{array}{l}\text { Accepted: } \\
\text { 04 May } 2019 \\
\text { Available Online: } \\
\text { 10 June } 2019\end{array}$ \\
\hline
\end{tabular}

The aim of the present study was to evaluate blood copper $(\mathrm{Cu})$, zinc $(\mathrm{Zn})$, Iron $(\mathrm{Fe})$ and Manganese (Mn) status of healthy goats (209) managed under semi intensive system in the three different agro-climatic zones of Punjab. For this purpose, two hundred nine blood and hair samples of various breeds of goats were taken. The samples were analyzed for trace minerals by using atomic absorption spectrophotometer (AAS) and the prevalence was recorded. Plasma $\mathrm{Cu}, \mathrm{Zn}$ and $\mathrm{Mn}$ concentrations were significantly $(\mathrm{P} \leq 0.05)$ different among the three zones. The mean plasma $\mathrm{Cu}(0.57 \pm 0.65 \mathrm{mg} / \mathrm{l})$ concentration was lowest in sub-mountainous zone, whereas $\mathrm{Zn}(1.73 \pm 0.12 \mathrm{mg} / \mathrm{l})$ and $\mathrm{Fe}(4.83 \pm 0.31 \mathrm{mg} / \mathrm{l})$ were lowest in central zone and $\mathrm{Mn}(0.81 \pm 0.07 \mathrm{mg} / \mathrm{l})$ was lowest in south-western zone. Hair concentration of $\mathrm{Mn}$ was significantly $(\mathrm{P} \leq 0.05)$ different among the zones, but $\mathrm{Cu}, \mathrm{Zn}$ and Fe had non-significant differences. Subclinical deficiency of copper (73\%) was the most prevalent trace mineral deficiency in goats followed by zinc and iron deficiencies. From the present study, it was clear that lower production and poor performance of goats in Punjab may be attributed to the trace mineral deficiency. Hence, regular supplementation of trace minerals is highly recommended.

\section{Introduction}

The most common reason to assess the trace mineral status of ruminants is because performance is below expectation. Accordingly, the assessment was done to determine the presence or prevalence of nutrient deficiencies (or toxicities) within a population. Assessment was also done to evaluate efficacy of dietary supplementation or to compare available supplements.

Physiological functions are progressively affected by deficiencies. For example, loss of pigmentation occurs with intakes of $\mathrm{Cu}$ that are sufficient for pregnancy maintenance and hemoglobin formation. Pregnancy is not maintained by intakes of $\mathrm{Cu}$ that prevent anemia. Furthermore, the disruption to $\mathrm{Fe}$ metabolism caused by $\mathrm{Cu}$ deficiency does not occur until after most other clinical signs have appeared (Mills, 1987). However, economically important effects on performance and health of animals can be affected by trace element deficiencies even before clinical signs are evident.

Mineral concentrations in goat blood are different from those of other ruminants such as cattle and sheep (Haenlein, 1980) and there 
is need to more fully understand its micromineral requirements. Age, breed, productivity, physiological state of animal, mineral intake, chemical form of elements and interrelationships with other nutrients, affect mineral requirements and status (Khan et al., 2007). The objective of the present work was to evaluate and compare microminerals status of goats of different zones on the basis of mineral concentrations in plasma and hair.

\section{Materials and Methods}

Healthy indigenous goats (209), from three different zones viz., I (south western zone), II (central zone) and III (sub mountainous zone), maintained under semi-intensive system and managed at different farms in villages of Punjab, were used in this study.Blood samples $(5 \mathrm{ml})$ were collected by jugular vein puncture, in nitric acid washed heparinised vials for harvesting plasma. The separated plasma samples were stored at $-20^{\circ} \mathrm{C}$ for pending analysis of minerals. Blood sample were digested as per AOAC (1984). Samples were processed for the estimation of $\mathrm{Cu}, \mathrm{Zn}, \mathrm{Fe}$ and Mn by atomic absorption spectrophotometer (Perkin Elmer AAnalyst700).

Hair samples were collected from body by following the standard procedures and were packaged in plastic bags of suitable size for further processing. Five hundred $\mathrm{mg}$ of each sample was digested with $6 \mathrm{ml}$ of double distilled nitric acid and kept overnight and heated over a hot plate below $80^{\circ} \mathrm{C}$ till digestion, followed by one cycle of Hydrogen Peroxide AR(2.0 $\mathrm{ml} 30 \%)$, until volume reduced to 1-2 $\mathrm{ml}$. The digested samples were diluted with double glass distilled water and the volume of the digestate was made $20 \mathrm{ml}$. Concentration of $\mathrm{Cu}, \mathrm{Zn}, \mathrm{Mn}$ and $\mathrm{Fe}$ were estimated by Atomic Absorption Spectrophotometer (Perkin Elmer A Analyst 700, USA).
Data was analyzed as per the method described by Snedecor and Cochran (1994) for mean and standard error.

\section{Results and Discussion}

\section{Plasma minerals}

Blood measures are frequently used in assessment because they are significantly correlated to nutritional status of some trace elements (Levander, 1986; Mills, 1987), and blood is less invasive to sample than liver.

The overall mean value for $\mathrm{Cu}$ was $0.98 \pm$ $0.04 \mathrm{mg} / \mathrm{l}$ (Table 1). It varied among the zones between $0.57 \pm 0.65$ and $1.09 \pm 0.06$ $\mathrm{mg} / \mathrm{l}$. The $\mathrm{Cu}$ concentration was significantly $(\mathrm{P} \leq 0.05)$ lower in zone III $(0.57 \pm 0.65 \mathrm{mg} / \mathrm{l})$ as compared to zone I and zone II (Table 1). Ullrey et al., (1977) reported that $0.7-1.5 \mathrm{mg} / \mathrm{l}$ should be considered normal plasma copper levels. Whole blood values of $\mathrm{Cu}$ below $0.7 \mathrm{mg} / \mathrm{l}$ or serum values below $0.5 \mathrm{mg} / \mathrm{l}$ signify hypocupraemia (Sharma et al., 2005). A large number of goat samples and a few of sheep samples at the unmanaged area were $\mathrm{Cu}$ deficient below the critical value of $0.65 \mathrm{mg} / \mathrm{l}$ (McDowell and Conrad 1977). Intakes of $\mathrm{Zn}$, $\mathrm{Fe}, \mathrm{Mo}$, and $\mathrm{S}$ affect $\mathrm{Cu}$ utilization (McDowell, 1992). Large intake of $\mathrm{Zn}$ reduces concentrations of $\mathrm{Cu}$ in plasma and liver of cattle and sheep (Kincaid et al 1976; Kellogg et al., 1989).

The mean value for $\mathrm{Zn}$ ranged between $1.73 \pm$ 0.12 and $2.76 \pm 0.24 \mathrm{mg} / \mathrm{l}$ among the three zones with overall mean value being $2.14 \pm$ $0.09 \mathrm{mg} / \mathrm{l}$ (Table 1). Mean concentration of $\mathrm{Zn}$ for zone II $(1.73 \pm 0.12 \mathrm{mg} / \mathrm{l})$ was significantly $(\mathrm{P} \leq 0.05)$ lower as compared to zone I and zone III. Comparatively lower $\mathrm{Zn}$ concentrations were recorded by Sarkar et al., (1995) who found mean plasma Zn levels of $1.08 \pm 0.11 \mathrm{ppm}$ in healthy goats in dry season and $1.12 \pm 0.16 \mathrm{ppm}$ in wet season. 
Plasma Zn concentrations in clinically normal calves and lambs were found to be 0.86 to 1.2 ppm (Mills 1987). Plasma Zn levels of goats in the present study were higher than these findings. Levels of Zinc in serum are highly dependent on factors like stress, trauma or diseases which influence levels of $\mathrm{Zn}$ containing enzymes such as carbonic an hydrase and alkaline phosphatase which can cause Zinc levels in serum to decrease (Graham, 1991).

Iron deficiencies, except in young ruminants (Mollerberg1975) do not normally occur in ruminants. The overall mean value for $\mathrm{Fe}$ was $5.05 \pm 0.23 \mathrm{mg} / \mathrm{l}$ in the goats of Punjab. It fluctuated among the zones between $4.83 \pm$ 0.31 and $5.64 \pm 0.52 \mathrm{mg} / \mathrm{l}$ without any significant difference among the zones (Table 1). Yatoo et al., (2013) estimated the serum mineral status, and hormonal profile of goats in Kashmir valley and recorded Mean \pm SE of plasma $\mathrm{Fe}$ in various districts viz., Budgam, Pulwama and Srinagar to be $1.48 \pm 0.14,1.52$ \pm 0.17 and $1.54 \pm 0.16 \mathrm{ppm}$, respectively. The values were comparatively lower than those in the present study. Significantly low levels of $\mathrm{Fe}$ and $\mathrm{Zn}$ concentration were observed in goats by Kalita et al., (2006).

The overall mean value for $\mathrm{Mn}$ was $0.99 \pm$ $0.04 \mathrm{mg} / \mathrm{l}$. It fluctuated among the zones between $0.81 \pm 0.07$ and $1.09 \pm 0.06 \mathrm{mg} / \mathrm{l}$. The mean value of zone I $(0.81 \pm 0.07 \mathrm{mg} / \mathrm{l})$ was significantly $(\mathrm{P} \leq 0.05)$ lower as compared to zone II and zone III (Table 1). The mean values of $\mathrm{Mn}$ in all the zones were higher than the critical value.

Symptoms of deficiency include poor growth and impaired reproduction, characterized by testicular atrophy in males (Hurley and Doane 1989) and slower exhibition of estrus and increased services per conception in females (Hidiroglou and Knipfel 1981). No specific clinical sign was observed in animals surveyed in the present study as the plasma Mn levels were well above the critical levels.

\section{Hair minerals}

Hair trace mineral concentrations of goats in various zones of Punjab are presented in Table 2 .

$\mathrm{Cu}$ deficiency in ruminants is often associated with depigmentation and impaired keratinization of hair. During the present study, overall mean value for $\mathrm{Cu}$ was $15.88 \pm$ $0.46 \mathrm{ppm}$. It varied non-significantly among the zones between $15.36 \pm 0.55$ and $16.86 \pm$ $0.88 \mathrm{ppm}$. Seasonal variation had been recorded in hair mineral concentrations by O'Mary et al., (1970) who collected hair from Hereford cattle in March and August and found higher concentrations of $\mathrm{Na}, \mathrm{Ca}, \mathrm{Cu}$, $\mathrm{Mg}, \mathrm{Mn}$ and $\mathrm{K}$ in the August samples.

The overall mean value for $\mathrm{Zn}$ was $120.49 \pm$ $1.17 \mathrm{ppm}$. It varied non-significantly among the zones between $117.97 \pm 3.19$ and 122.48 $\pm 1.78 \mathrm{ppm}$ during the study. Miller et al (1965) reported a seasonal pattern for $\mathrm{Zn}$ accumulations in hair of Holstein cattle. Hairs collected in November were lower in $\mathrm{Zn}$ than hair collected at any other time of year. Reinhold et al., (1968); Deeming and Weber (1977) concluded that $\mathrm{Zn}$ levels in hair are related to dietary $\mathrm{Zn}$ levels but do not necessarily reflect the severity of $\mathrm{Zn}$ deficiency, as manifested by impaired growth rates. In research with ruminants, Miller et al., (1966) and Miller (1970) reported that $\mathrm{Zn}$ concentrations in hair reflected dietary $\mathrm{Zn}$ levels of cattle and goats more consistently than concentrations in any other tissue. Miller et al., (1966) noted, however, that because of variation among animals, $\mathrm{Zn}$ deficiency could not be adequately diagnosed by hair analyses.

The overall mean value for $\mathrm{Fe}$ was $121.03 \pm$ $1.67 \mathrm{ppm}$. It varied non-significantly among 
the zones between $120.12 \pm 3.16$ and 123.81 $\pm 3.13 \mathrm{ppm}$ throughout the period of study.

The overall mean value for $\mathrm{Mn}$ was $4.79 \pm$ $0.23 \mathrm{ppm}$. It fluctuated between $4.12 \pm 0.48$ and $5.46 \pm 0.45 \mathrm{ppm}$ among the three zones. Mn was significantly $(\mathrm{P} \leq 0.05)$ higher in zone II $(5.46 \pm 0.45 \mathrm{ppm})$ as compared to zone III and was supported by higher plasma $\mathrm{Mn}$ levels in that zone. On the other hand, a study by Haenlein and Anke (2011) reported that Mn-deficient nutrition had no impact on the Mn concentration in blood serum of goats but it reduces the Mn content in organs (liver, kidney, heart, muscle) and hair. Skibniewski et al., (2010) reported that hair is a very good indicator of the degree of manganese supply in animals.

Table.1 Plasma trace mineral concentrations of goats in various zones of Punjab (Mean \pm SE)

\begin{tabular}{|l|l|l|l|l|l|}
\hline Zones & No. of goats & $\mathbf{C u}(\mathbf{m g} / \mathbf{l})$ & $\mathbf{Z n}(\mathbf{m g} / \mathbf{l})$ & Fe $(\mathbf{m g} / \mathbf{l})$ & $\mathbf{M n}(\mathbf{m g} / \mathbf{l})$ \\
\hline Zone- I & 66 & $1.01 \pm 0.08$ & $2.47 \pm 0.16$ & $5.09 \pm 0.44$ & $0.81 \pm 0.07 *$ \\
& & $(0.04-2.14)$ & $(0.15-5.58)$ & $(1.03-16.22)$ & $(0.12-2.14)$ \\
\hline Zone- II & 108 & $1.09 \pm 0.06$ & $1.73 \pm 0.12^{*}$ & $4.83 \pm 0.31$ & $1.09 \pm 0.06$ \\
& & $(0.02-3.71)$ & $(0.12-6.45)$ & $(0.14-15.54)$ & $(0.12-2.85)$ \\
\hline Zone- III & 35 & $0.57 \pm 0.65^{*}$ & $2.76 \pm 0.24$ & $5.64 \pm 0.52$ & $0.99 \pm 0.11$ \\
& & $(0.01-1.50)$ & $(0.11-6.21)$ & $(0.25-12.56)$ & $(0.12-2.63)$ \\
\hline Total & 209 & $0.98 \pm 0.04$ & $2.14 \pm 0.09$ & $5.05 \pm 0.23$ & $0.99 \pm 0.04$ \\
& & $(0.01-3.71)$ & $(0.11-6.45)$ & $(0.14-16.22)$ & $(0.12-2.85)$ \\
\hline Deficiency \% & 73 & 15 & 18 & - \\
\hline
\end{tabular}

*P $\leq 0.05$ - significant difference in a column.

Figures given in parenthesis indicate range of parameters

Table.2 Mineral concentrations in hair samples of goats in various zones of Punjab (Mean \pm SE)

\begin{tabular}{|c|c|c|c|c|c|}
\hline Zones & \begin{tabular}{|l|}
$\begin{array}{l}\text { No. of } \\
\text { goats }\end{array}$ \\
\end{tabular} & $\mathrm{Cu}(\mathrm{ppm})$ & Zn (ppm) & $\mathrm{Fe}$ (ppm) & Mn (ppm) \\
\hline Zone- I & 66 & $\begin{array}{l}15.36 \pm 0.55 \\
(6.23-26.28)\end{array}$ & $\begin{array}{l}119.97 \pm 1.74 \\
(99.52-145.52)\end{array}$ & $\begin{array}{l}120.78 \pm 2.38 \\
(69.46-192.25)\end{array}$ & $\begin{array}{l}4.56 \pm 0.30 \\
(0.15-11.01)\end{array}$ \\
\hline Zone- II & 108 & $\begin{array}{l}16.86 \pm 0.88 \\
(6.67-29.36)\end{array}$ & $\begin{array}{l}122.48 \pm 1.78 \\
(100.63-146.87)\end{array}$ & $\begin{array}{l}120.12 \pm 3.16 \\
(60.52-154.52)\end{array}$ & $\begin{array}{l}5.46 \pm 0.45^{*} \\
(1.02-12.84)\end{array}$ \\
\hline Zone- III & 35 & $\begin{array}{l}15.54 \pm 1.37 \\
(6.67-29.36)\end{array}$ & $\begin{array}{l}117.97 \pm 3.19 \\
(99.52-143.36)\end{array}$ & $\begin{array}{l}123.81 \pm 3.13^{*} \\
(100.24-143.36)\end{array}$ & $\begin{array}{l}4.12 \pm 0.48 \\
(0.64-8.45)\end{array}$ \\
\hline Total & 209 & $\begin{array}{l}15.88 \pm 0.46 \\
(6.23-29.36)\end{array}$ & $\begin{array}{l}120.49 \pm 1.17 \\
(99.52-146.87)\end{array}$ & $\begin{array}{l}121.03 \pm 1.67 \\
(60.52-192.25)\end{array}$ & $\begin{array}{l}4.79 \pm 0.23 \\
(0.15-12.84)\end{array}$ \\
\hline
\end{tabular}

$* \mathrm{P} \leq 0.05$ - significant difference in a column

Figures given in parenthesis indicate range of parameters

Assessment of trace element status identifies whether current feeding status or mineral supplementation of livestock is adequate and whether improved productivity is likely to occur with changes in supplementation. Based on the present findings, it can be concluded that the goats in Punjab are predisposed to trace mineral deficiencies under the present feeding systems. This study indicated that subclinical trace mineral deficiency may be prevalent in geographical regions covered in this study. Nearly 73 per cent goats were sub- 
clinically deficient in $\mathrm{Cu}$ (Table 1), with deficiency being significantly $(\mathrm{P} \leq 0.05)$ higher in zone III. Plasma $\mathrm{Zn}$ and Fe concentrations were significantly $(\mathrm{P}<0.05)$ low in zone II with overall deficiency being 15 and 18 percent, respectively. Hence, balanced feeding of $\mathrm{Cu}, \mathrm{Zn}$ and $\mathrm{Fe}$ in the diet of indigenous goats is very essential for optimum growth, production and reproduction.

\section{References}

AOAC. 1984. Official Methods of Chemical Analysis. Association of Official Analytic Chemists. pp 444-76. Virginia.

Deeming S B and Weber C W. 1977.Evaluation of hair analysis for determination of zinc status using rats. American Journal of Clinical Nutrition, 30(12):2047-52.

Graham T W. 1991. Trace element deficiencies in cattle. Veterinary Clinics of North America: Food Animal Practice 7: 153-215.

Haenlein G F and Anke M. 2011. Mineral and trace element research in goats: a review. Small Ruminant Research 95(1): 2-19.

Haenlein G F W. 1980. Mineral nutrition of goats. Journal of Dairy Science, 30: 1729-42.

Hidiroglou M and Knipfel J E. 1981. Maternal fetal relationships of copper, manganese, and sulfur in ruminants- A review. Journal of Dairy Science, 64: 1637-47.

Hurley W L and Doane R M. 1989.Recent developments in the roles of vitamins and minerals in reproduction. Journal of Dairy Science, 72: 784-804.

Kalita D J, Sarmah B C, Bhattacharyya B N and Milli D C. 2006. Serum mineral profile of Assam local goat of hills zone during different physiological stages. Indian Journal of Animal Research, 40(1):93-94.

Kellogg D W, Rakes J M and Gliedt D W. 1989. Effect of zinc methionine supplementation on performance and selected blood parameters of lactating dairy cows. Nutrition reports international, 40(6): 1049-57.

Khan Z I, Hussain A, Ashraf M, Ashraf M Y, McDowell L R and Huchzermeyer B. 2007. Copper nutrition of goats grazing native and improved pasture with the seasonal variation in a semiarid region of Pakistan. Small Ruminant Research, 67(2):138-48.

Kincaid R L, Miller W J, Fowler P R, Gentry R P, Hampton D L and Neathery $M$ W. 1976. Effect of high dietary zinc upon zinc metabolism and intracellular distribution in cows and calves. Journal of dairy science 59(9): 1580-84.

Levander O A. 1986. The need for measures of selenium status. International Journal of Toxicology 5(1): 37-44.

McDowell L R. 1992. Copper and molybdenum. Minerals in animal and human nutrition. Pp. 176-204.

McDowell L R and Conrad J H. 1977. Trace mineral nutrition in Latin America [ruminants]. World Animal Review 24, 24.

Miller W J, Blackmon D M, Gentry R P, Powell G W and Perkins H F. 1966. Influence of zinc deficiency on zinc and dry matter content of ruminant tissues and on excretion of zinc. Journal of Dairy Science, 49(11): 1446-53.

Miller W J, Powell G W, Pitts W J and Perkins H F. 1965. Factors affecting zinc content of bovine hair. Journal of Dairy Science, 48(8): 1091-95.

Miller W J. 1970. Zinc nutrition of cattle: a review. Journal of Dairy Science, 53(8): 1123-35. 
Mills C F. 1987. Biochemical and physiologic indicators of mineral status in animals: copper, cobalt, and zinc. Journal of Animal Science, 65: 1702-11.

Mollerberg L. 1975. Hematological and blood chemical study of Swedish purchased calves. Acta veterinaria scandinavica 16(2): 170-77

O'Mary C C, Bell M C, Sneed N N and Butts W T. 1970. Influence of ration copper on minerals in the hair of Hereford and Holstein calves. Journal of Animal Science, 31(3): 626-30.

Reinhold J G, Kfoury G A and Arslanian M. 1968.Relation of zinc and calcium concentrations in hair to zinc nutrition in rats. Journal of Nutrition, 96: 51924.

Sarkar S, Bhowmik M K and Biswas S. 1995. Micromineral deficiency anaemia in grazing goats with a therapy note. Indian Journal Veterinary Pathology, 19(2): 108-11.

Sharma M C, Joshi C and Kumar M. 2005.
Micro mineral deficiency disorders and treatment: A review. Indian Journal of Animal Science, 75: 24657.

Skibniewski M, Kośla T and Skibniewska E. 2010. Manganese status in free ranging European bisons from Bialowieza Primeval Forest. Bulletin of the Veterinary Institute in Pulawy, 54: 429-32.

Snedecor G W and Cochran W G. 1994. Statistical Methods 21(4): 846-855

Ullrey P S, Brady P S, Whetter P A, Ku P K. and Maggie W T. 1977. Selenium supplementation of diets for sheep and beef cattle. Journal of Animal Science, 46: 559-65.

Yatoo M I, Saxena A, Kumar P, Gugjoo M B, Dimri U, Sharma M C and Jhambh R. 2013. Evaluation of serum mineral status and hormone profile in goats and some of their inter-relations. Veterinary World, 6(6): 318-20.

\section{How to cite this article:}

Gurwinder Singh, Sushma Chhabra and Uppal, S.K. 2019. Trace Mineral Status in Goats in Different Zones of Punjab State, India. Int.J.Curr.Microbiol.App.Sci. 8(06): 90-95. doi: https://doi.org/10.20546/ijcmas.2019.806.012 